\title{
ARCHEOLOGICKÉ VÝZKUMY ING. B. COUFALA V AREÁLU HRADU ROKŠTEJN ${ }^{1}$
}

\author{
JANA MAZÁČKOVÁ - DANIELA VANĚČKOVÁ
}

Abstrakt: Článek vyhodnocuje amatérský archeologický výzkum Ing. Bohumila Coufala v areálu hradu Rokštejna a pokouši se propojit jeho maximální informační potenciál se stávajícím systematickým výzkumem hradu. Prostřednictvím analýzy dokumentace jeho výzkumu, především terénních deníkủ a fotografické dokumentace z let 1958-1965, se snažíme detekovat v areálu hradu plochy exkavované Coufalem, dostavěné a rekonstruované stavby a tř́dit jím získané artefakty, a to prozatím kovový inventár z horního paláce.

Kličová slova: středověk-hrad-Rokštejn-amatérský výzkum-kovové artefakty.

\section{Archaeological research by Bohumil Coufal at Rokštejn Castle}

Abstract: This article assesses amateur archaeological research conducted by Ing. Bohumil Coufal at the Rokštejn castle, combining its high informative potential with the current systematic investigation of the castle. With the analysis and documentation of Ing. Coufal's research, especially his field diaries and photographic documentation from 1958-1965, the project aims to determine within the castle complex areas excavated by Coufal, completed and reconstructed structures and sort out the artefacts from his excavations, currently metal items from the upper palace.

Key words: Middle Ages - castle - Rokštejn-amateur research-metal artefacts.

\section{1 Úvod}

Zřícenina hradu Rokštejna se rozkládá na nevysokém skalním suku v romantickém údolí dolního toku řeky Brtnice (okres Jihlava). Hrad je významný nejen z hlediska architektonického vývoje, ale i politických událostí 14. a 15. století. Není pozoruhodný pouze svým vzhledem, ale také dlouhodobým archeologickým výzkumem. V roce 1981 byl zahájen záchranný archeologický výzkum v souvislosti s plánovanou výstavbou vodního díla Stř́ižov. Exkavace byly prováděny Archeologickým ústavem ČSAV v Brně pod vedením Zdeňka Měřínského až do roku 1988, kdy nakonec z realizace vodního díla sešlo. Na záchranný výzkum v roce 1989 navázal výzkum systematický, který převzalo Moravské zemské muzeum v Brně (MZM), opět pod vedením Z. Měřínského. V roce 1991 se výzkumu ujala Filozofická fakulta Masarykovy univerzity, prvních šest let byl výzkum prováděn pod vedením Historického ústavu a od roku 1996 dodnes je veden Ústavem archeologie a muzeologie. Do roku 2016 stál v jeho čele Z. Měřínský, v roce 2017 jej převzala Jana Mazáčková (Mazáčková 2012, 83-84, 92; Měřínský 2007, 8).

Záchranným a systematickým archeologickým výzkumům předcházel amatérský terénní odkryv. Jeho iniciátorem se stal amatérský badatel Ing. Bohumil Coufal. Výzkum probíhal v 60. a 70. letech 20. století s povolením Moravského zemského muzea a Krajského muzea v Jihlavě. Zhodnocení výsledků amatérského archeologického výzkumu, dozdění a opravy kamenného zdiva hradu $\mathrm{z}$ iniciativy $\mathrm{B}$. Coufala zahrnuje př́nosy i negativa jeho působení v areálu hradu Rokštejna.

\section{Ing. Bohumil Coufal}

Ing. Bohumil Coufal (obr. 1) se narodil 18. srpna 1907 v Kosově u Jihlavy. Jeho otec Emil Coufal odkoupil v roce 1906 nemovitosti, které se nacházely v blízkosti hradu Rokštejna. Jednalo se o bývalou papírnu a její provozní budovy, které se přesně nacházely na severovýchodním parkánu a severním předhradí hradu. Budova papírny byla roku 1908 předělána na moderní mlýn na obilí, který byl od roku 1920 vybaven Francisovou turbínou a začal dodávat elektrický

1 Tento článek vychází z bakalářské práce, která se zabývala archeologickými výzkumy Ing. B. Coufala v areálu hradu Rokštejn (Vaněčková 2017). 


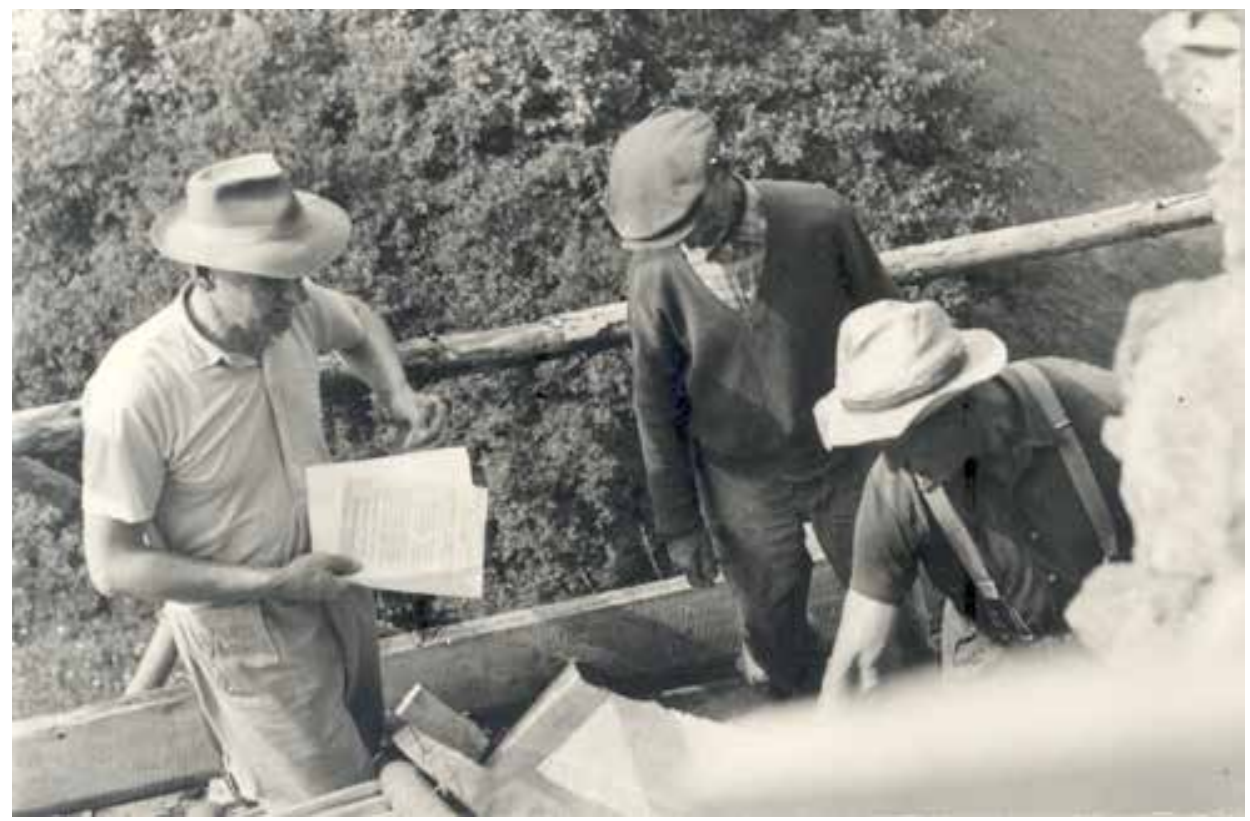

Obr. 1. Ing. B. Coufal při rekonstrukčních pracích na zdivu hradu v roce 1964. Autor B. Coufal, pozůstalost B. Coufala, archiv ÚAM.

Abb. 1. Ing. B. Coufal bei Rekonstruktionsarbeiten am Mauerwerk der Burg im Jahr 1964. Foto B. Coufal, Nachlass B. Coufal, Archiv Institut für Archäologie und Museologie.

proud do okolních vesnic. Mlýn fungoval do roku 1958; roku 1990 vyhořel. Budova na severním předhradí byla přebudována na rodinný dům, ve kterém $B$. Coufal prožil celé dětství a většinu života. Jeho rodina zde žije dodnes (Mazáčková 2012, 10, 67, 518; Vaněčková 2017, 19).

B. Coufal se intenzivně věnoval vlastivědnému a archeologickému bádání v mikroregionu Černé lesy, hlavně kolem vesnic Př́imělkov a Panská Lhota na Jihlavsku. V letech 1957 a 1960 provedl své první amatérské exkavace na opevněném hrádku v trati Přímělkov - Spády, která se nachází na ostrožně nad soutokem řek Jihlavy a Brtnice asi $1,5 \mathrm{~km}$ východně od hradu Rokštejna. Výsledky svého výzkumu a dějiny Přímělkova s editací pramenů týkajících se přímělkovské tvrze shrnul ve dvou článcích, které měly vyjít ve Vlastivědném sborníku Vysočiny (roč. VI, 1970), nakonec však ani jeden článek nebyl publikován (Měřínský 1990, 428; Vohryzek 2009, 10).

Kromě historie Přímělkova se zabýval i jinými tématy, například rybníkářstvím v mikroregionu nebo vývojem školství v Panské Lhotě, hlavně se však soustředil na sběr pramenů o hradě Rokštejn. Bohužel výsledky všech těchto studií zůstaly jen v podobě rukopisných poznámek.

Na hradě Rokštejn B. Coufal prováděl amatérský archeologický výzkum v letech 19581965, a to s vědomím MZM a Národního výboru v Jihlavě. Na hradě zkoumal vedle jiného kanál u tzv. kovárny v areálu dolního hradu, prostor A horního paláce, prostor B dolního paláce, jihozápadní roh nádvoří horního hradu a bránu na nádvoří dolního hradu. Kromě archeologického výzkumu i zrekonstruoval a zabezpečil některé části narušeného hradního zdiva - jihozápadní nároží hradby horního hradu, hradby v úseku severně od věže dolního hradu ve čtvercích 14/13 a 14/14 a dostavěl bránu dolního hradu (Vaněčková 2017, 20).

B. Coufal za svůj život spolupracoval s celou řadou badatelů, např́íklad s dr. V. Fialovou, CSc., dr. F. Hoffmannem, CSc., dr. V. Nekudou, CSc., a A. Kábou. Svou prací přispěl 


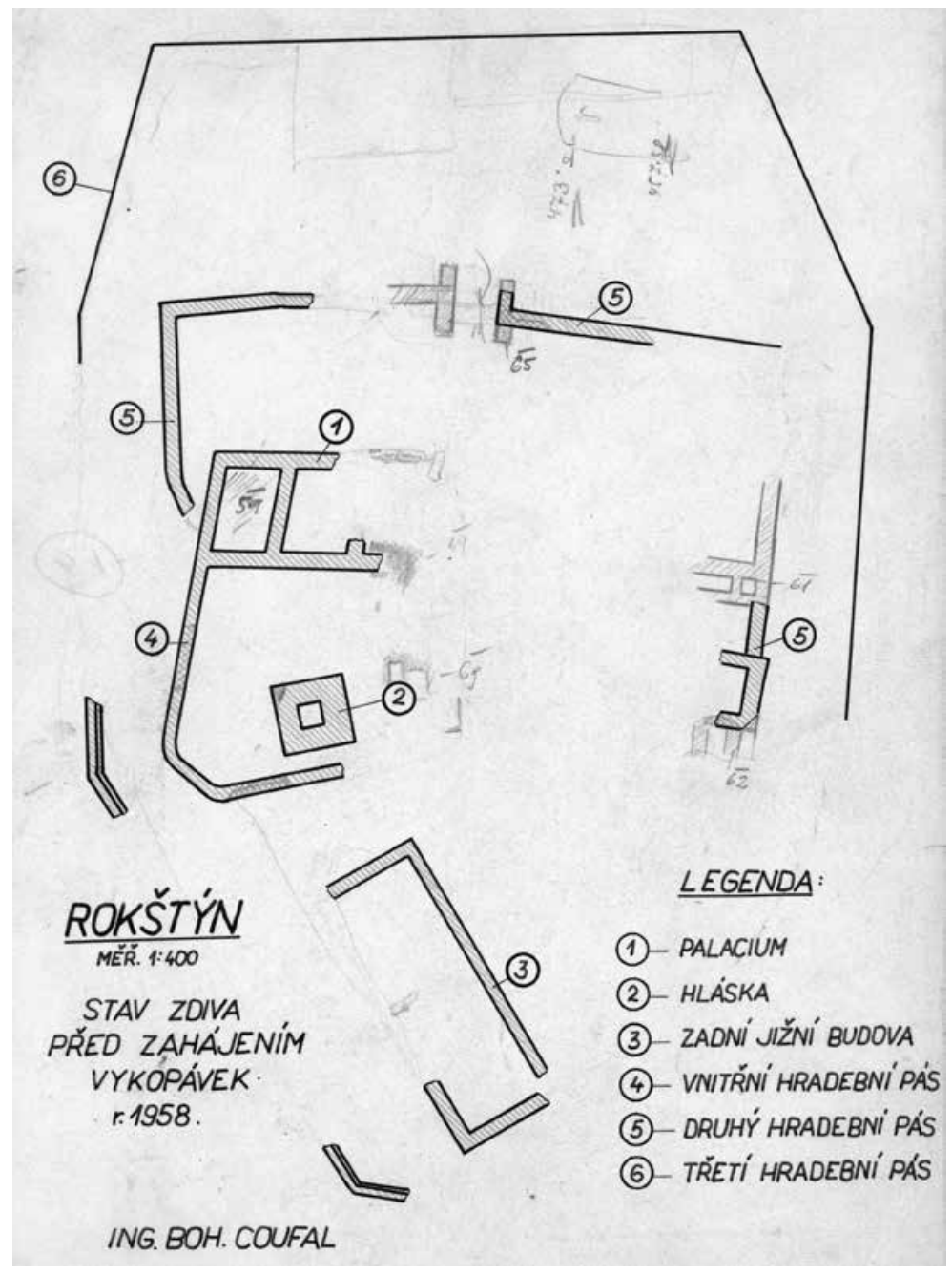

Obr. 2. Plán hradu od B. Coufala vytvořený v roce 1958 a částečně upravovaný s postupem prací v areálu hradu. Autor B. Coufal, pozůstalost B. Coufala, archiv ÚAM, upraveno.

Abb. 2. Plan der Burg von B. Coufal, erstellt im Jahr 1958 und mit fortschreitender Arbeit im Burgareal teilweise abgeändert. Erstellt von B. Coufal, Nachlass B. Coufal, Archiv Institut für Archäologie und Museologie, bearbeitet.

k poznání historie mikroregionu na dolním toku Brtnice i k záchraně hradu Rokštejna. Zemřel 24. dubna 1990 ve věku 82 let v Jihlavě (Měřínský 1990, 428).

\section{Coufalovy exkavace na hradě Rokštejn}

V průběhu let 1958-1960 prováděl B. Coufal exkavační práce v areálu hradu Rokštejna, záznamy z terénních deníků uvádí několik sond. Práce po roce 1960 jsou rekonstruovány především z fotografické dokumentace $\mathrm{B}$. Coufala a jedná se vesměs o statické zajištění zdiva nebo jeho dostavby v letech 1961, 1962, 1965 a 1969 (obr. 2). 
Na konci března roku 1958 začal B. Coufal se svolením MZM a Krajského muzea v Jihlavě exkavační práce na hradě Rokštejn (obr. 3). Jeho výzkum započal prokopáním věže horního hradu a horního paláce. B. Coufal otevřel v areálu hradu současně několik sond. Sondy byly položeny u vnější strany severní zdi dolního paláce, v horním či dolním paláci. Snažil se najít hradní studnu a objevit exkluzivní nálezy v interiérech obou paláců. Dále zkoumal průběh hradebních zdí, hlavně v prostoru v blízkosti východní obvodové hradby dolního hradu. Zde narazil na komín a na něj napojený dlážděný kanál. V tomto prostoru odkryl i úsek hradby navazující na východní věž dolního hradu (Coufal 1958, 3-10). Na konci výzkumu v roce 1958 odkryl ještě několik situací u vstupu do dolního paláce. Zde potom navázal odkryvem v roce 1959, kdy prokopal prostor $\mathrm{B}$ dolního paláce až na skalní podloží. K jeho počinům pravděpodobně náleží i sonda $\mathrm{v}$ prostoru $\mathrm{C}$ dolního paláce, a to $\mathrm{v}$ severozápadním rohu této části stavby, která kopírovala roh, měla tedy tvar písmene $\mathrm{L}$. Tato sonda není uváděna $\mathrm{v}$ terénních denících a objevena byla až při systematickém archeologickém výzkumu v letech 2005-2007 (Mazáčková 2012, 85-86). Kvůli horkému počasí se Coufal posléze přesunul z dolního do horního paláce. Zde nechal kopat situace v prostoře A, kterou vytěžil až na skalní podloží (Coufal 1957-1960, 11-24). Nakonec se přesunul k vstupní bráně do dolního hradu a nejbližšího branského prostoru. Odkrytou situaci u branského prostoru a bránu samotnou stavebně „,zrekonstruoval“. Z této exkavační práce však už neexistuje žádný terénní deník, dochovaly se jen žánrové snímky z různých etap stavebních prací na substrukci zdiva brány (Mazáčková 2012,87).

\subsection{Metodologie výzkumu}

Za položením různě plošně velkých sond byl vždy nějaký specifický cíl topografie hradu a odhalení zdiva a provozních objektů. Přesto nejčastějším záměrem všech odkryvů bylo vyzvednutí co největšího počtu exkluzivních nálezů. Velikosti sond (obr. 3) kolísaly podle potřeby a velikosti zkoumaného prostoru $\mathrm{v}$ interiéru stavby.

Metodu Coufalova terénního výzkumu hradního areálu lze charakterizovat jako záměrnou sondáž všech stavebních objektů a jejich blízkého okolí se snahou o zjištění maxima informací o průběhu pohřbeného zdiva. Místa různě velkých sond byla dopředu vybrána záměrně s předpokladem odkrytí velkého množství zajímavých artefaktů. Chaotické přesouvání zájmu po areálu hradu spojuje jen nesystematický odkryv, terénní dokumentace a popis situací. Místa sondáží jsou popsána zběžně, rozměry sond nejsou uváděny vůbec, samy sondy nejsou ani řádně zapsány v terénním deníku. Při výkopu pravděpodobně také nebyl kladen důraz na stratigrafii vrstev, nebo nebyla vynaložena snaha o jejich řádnou dokumentaci. V terénních denících se dochovalo pouze pár strohých záznamů se slovním popisem stratigrafické situace, především pro horní palác. Neexistuje k nim však žádná terénní kresebná dokumentace. Dohledat lze jen několik žánrových snímků z exkavací, na nichž průběh sondy nebo zvrstvení není dobře čitelné. Nejlépe je popsána stratigrafická situace v horním paláci, která je $\mathrm{v}$ denících uvedena několikrát (Vaněčková 2017, 34, 39).

Snahou B. Coufala bylo sondy co nejrychleji odtěžit až na podloží. Jak již bylo uvedeno výše, jeho hlavním cílem stále bylo získání co největšího množství artefaktů. Pro nedostatek volného místa na další výkopy musel být často už vytěžený materiál přesouván na jiná místa, kde tzv. nepřekážel. Tato hlína byla znovu překontrolována (Coufal 1958, 7). Později byl kvůli maximálnímu zajištění artefaktů vytěžený materiál prohazován na prohazovačce - takto byla objevena keramika včetně dlaždic i s novým reliéfním motivem, hřebíky a udidlo původně z prostoru B dolního paláce (Coufal 1959, 17). Hrad, sondy a artefakty nebyly nikdy geodeticky zaměřeny, nicméně existují Coufalovy terénní plánky hradu se zaznamenáním některých odkrývaných míst (Vaněčková 2017, 34).

Vybírání a následné ošetření artefaktů není v deníku nijak popsáno, ani není uvedeno jejich roztřídění podle místa sond. Některý materiál byl tříděn podle míst odkryvů, ale nikoliv podle vrstev, nebo nějakého jiného systému, podle nějž by bylo možné zpětně identifikovat původ artefaktů. 


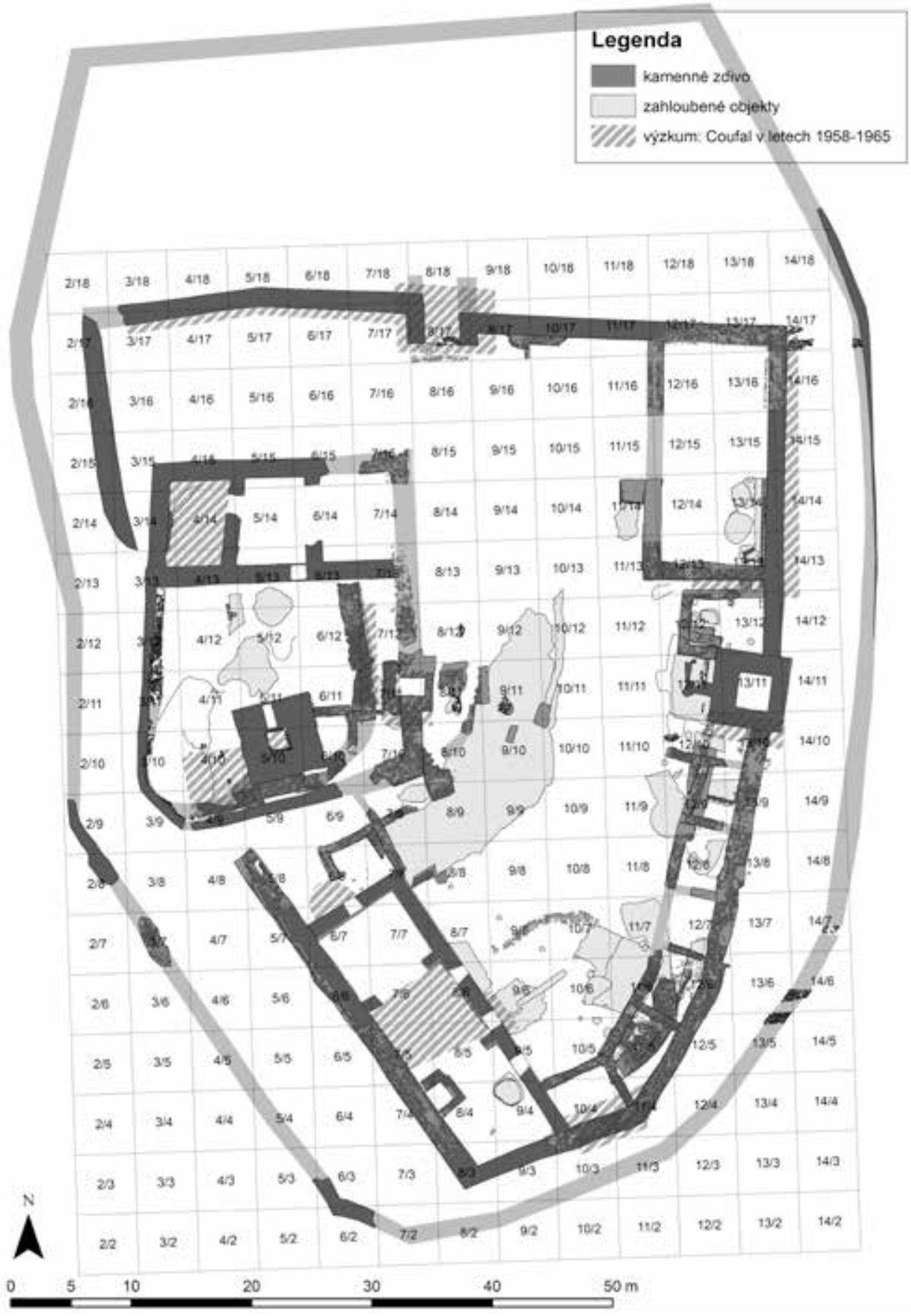

Obr. 3. Exkavační práce B. Coufala na hradě Rokštejn v letech 1958-1960.

Abb. 3. Aushebungsarbeiten von B. Coufal auf Burg Rokštejn in den Jahren 1958-1960. 
Více informací lze zjistit z dochované fotodokumentace. Na některých fotografiích lze odhalit nakupení nalezených předmětů vedle sond. Na dalších fotografích jsou zachyceny papírové sáčky a bedničky, do kterých byly nálezy ukládány, a patrně i rozdělovány podle druhu nálezu (na keramiku, železo, kosti atd.). Následně byly artefakty deponovány v domě B. Coufala, jak nám dokládají dva zápisy z deníku. V prvním zápisu píše, že dlaždice a střepy uložil ve svém bytě na Rokštejně a kovové předměty odvezl do Krajského muzea v Jihlavě. V druhém zápisu se uvádí, že nálezy jsou u B. Coufala (Coufal 1957-1960, 12, 32). Podle terénního deníku byly i některé střepy čištěny a tříděny (Coufal 1957-1960, 25). Z fotografií lze doložit lepení střepů a rekonstruování nádob (Vaněčková 2017, 35).

\subsection{Zkoumané části hradu}

Výzkum věže horního hradu probíhal čtyři pracovní dny v období od března do července 1958. Situace byla odkryta až na skalní podloží. Během prvního dne byla odtěžena vrstva o mocnosti $1 \mathrm{~m}$ s nálezem kamenického článku. Jiné nálezy nejsou popsány a B. Coufal v terénním deníku uvádí situaci ve věži bez nálezů.

Výzkum v paláci, tedy v paláci horního hradu probíhal v roce 1958. Zmíněno je jen několik korýtek (prejzy). Zde se pokračovalo ve výzkumu až v roce 1959 (Coufal 1959, 23).

Popis situace v horním paláci je nejpodrobnější. Vrstva suti jde až do hloubky $80 \mathrm{~cm} / 120$ $150 \mathrm{~cm}$ od povrchu a je složená z kamení a malty. Pod ní je vrstva tzv. červené sutě složené z prejzů (střešní krytiny), má mocnost $25-50 \mathrm{~cm}$ a její průběh je nepravidelný. $V$ porovnání se situací v dolním paláci se zdá na množství nižší zastoupení prejzů v horním paláci, a to především malé úlomky, i v podobě sypké červené hlíny až písku. Pod vrstvou této červené sutě se objevily keramické střepy nádob, dále silné hřebíky, sporadicky zuhelnatělé části dřeva a následovalo skalní podloží. Skála probíhá ostrými nízkými hřbety směrem jih-sever, v severozápadním rohu je doložena maltová vyrovnávka. Sut' zde seděla většinou až na skále bez stop jakékoliv formy podlahy, např́íklad hliněné (Coufal 1959, 24, 29-31). Mezi další nálezy patří fragment krakorce z destruovaného krbu ve čtvrtém podlaží v jihozápadním rohu paláce, zbytek cihly s otisky psích tlap, v hloubce $150 \mathrm{~cm}$ po povrchem kamenné ostění dveři či plechové kování z dvířek (Coufal 1959, 26-29).

Zjištění půdorysu hradu vedlo k odkrytí zdiva mezi palácem a věží horního hradu, zde byla odkryta hradba horního hradu (čtverce 6/11-6/13 a 7/11-7/13). Dále se výzkum zaměřil na severovýchodní část hradního areálu a na tzv. Coufalovo odklízení situací kolem cesty Přímělkov směr Panská Lhota, kde se soustředilo na odrytí průběhu zdiva obvodové hradby severně a jižně od věže dolního hradu (čtverce 13/12 a 13/13). V severním úseku hradby byly nalezeny dvě šipky, jedna s tulejí a druhá s trnem, a dále několik kovaných hřebíků (Coufal 1958, 8). V jižním úseku bylo zkoumáno demolované nároží věže dolního hradu a odkryta obvodová hradba (Coufal 1958, $11 ; 1959,13)$.

V úseku severně od věže horního hradu byl odkryt $t z v$. komín / zděná šachta o rozměrech $90 \times 90 \mathrm{~cm}$. Mezi nálezy se objevily keramické střepy a kosti - podle Coufalova hodnocení z drůbeže, kohoutí nohy, hovězí a kančí s čelistmi a tesáky. Kamenná destrukce byla odebrána až na dlážděné dno kanálu o mírném spádu směrem ven $\mathrm{z}$ hradu. Interpretace situace: pravděpodobně jde o odpadní kanál. Výzkum pokračoval směrem od šachty do vnitřního areálu hradu. V délce $5 \mathrm{~m}$ a do hloubky ca $80 \mathrm{~cm}$ se jedná o úzkou chodbu o šířce $70 \mathrm{~cm}$ po obou stranách zdi. Mezi nálezy v chodbě jsou keramické střepy a železná struska - v některých případech miskovitého tvaru, dva třmeny. Jeden ze třmenů byl plechový, na horní části přričky asi pocínovaný (Coufal 1958, 6).

Dolni palác prostor $B$ byl zkoumán postupně. Nejdříve byl exkavován prostor vstupu do suterénu paláce, prričemž úroveň podlahy suterénu se předpokládala o $1,5 \mathrm{~m}$ níže než plocha nádvoří. Sonda pokračovala $v$ interiéru paláce podél východní zdi severním směrem. Mezi nálezy se objevila keramika a hřebíky. Pod kamennou destrukcí v hloubce asi $100 \mathrm{~cm}$ byla vrstva téměř ze samých úlomků prejzů, mezi nimiž se nacházely reliéfní i nereliéfní dlaždice o rozměrech 
$17 \times 17 \times 3 \mathrm{~cm}$. Mezi zjištěnými motivy jsou lilie nebo erbovní symboly. Mezi dalšími nálezy jsou hřebíky, podle Coufalova určení „krováky“, dále zámky, panty, řetězová petlice, kosa, zbytek pořízu, patrně kování jezdeckého sedla podle určení B. Coufala a jedna šipka. Prostor výzkumu se rozšíríl do celé plochy prostoru B a zachycena byla západní zed’ paláce. „Na průřezu sondy je vidět vždy v nejspodnějši vrstvě spálené krovy - uhli výše pak malta a sut'." V traktu byly objeveny zbytky původních zděných příček rozdělujících palác na prostor A-C. Výzkum se na konci roku 1958 pohyboval v hloubce $3 \mathrm{~m}$. Kovové nálezy jako hřebíky, panty, petlice či třmen odvezl B. Coufal do Krajského muzea v Jihlavě, ostatní nálezy jako dlaždice a střepy deponoval „v bytě na Rokštýne““ (Coufal 1958, 9-11). Při výzkumu v roce 1959 píše B. Coufal pouze o vyvážení suti a nálezech jako dlaždicích, hřebíkách a částech plechů, ale dne 8. července 1959 došlo k odkrytí situace zuhelnatělé zřícené dřevěné konstrukce. Dokonce uvádí: „Několikrát jsme jej fotografovali a shlédli jej ihned pracovníci Krajského musea v Jihlavě. Soudruzi A. Kába a archeolog $s$. Meduna“ (Coufal 1959, 23). Mezi další nálezy z roku 1959 patří např́íklad zbytek dýky a vědra (Coufal 1959, 27).

Nádvoři horniho hradu (sonda ve čtvercích 4/10 a 3/10) bylo zkoumáno v listopadu až prosinci roku 1959 (Coufal 1959, 31-32). Přri západní zdi věže horního hradu byly odkryty tři kamenné stupně skalního podloží, mezi nálezy se objevily keramika, hřebíky a kosti. V hloubce asi $0,5 \mathrm{~m}$ byla objevena zuhelnatělá půda a $\mathrm{v}$ ní asi tři zbytky trámků.

Brána do dolního hradu byla rekonstruována v roce 1965, výzkum rekonstrukci předcházel. K tomuto úseku výzkumu není dochována žádaná písemná forma dokumentace, jen několik žánrových snímků.

\subsection{Dokumentace výzkumu}

Průběh výzkumu se B. Coufal snažil zaznamenávat do terénního deníku, který si vedl. Deník je nadepsán Vykopávky Rokštýn a celkově má popsáno 37 stran formátu A4. Deník od sebe odlišuje jednotlivé sezóny výzkumu velkým nadpisem a pak je rozdělen podnadpisy jednotlivých dnů, kdy se kopalo. Deník je veden systematicky, každý zápis je nadepsán datem, dále je uvedeno, kdo ten den pracoval (uvedena jsou celá jména a k nim počet odpracovaných hodin, někdy je uvedeno trvalé bydliště nebo číslo občanského průkazu), pak následuje samotný zápis. Málokdy se však zápisy týkají výzkumu nebo popisu odkrytých situací, jen zběžně jsou uvedena místa výkopu. Pokud se ten den nalezly nějaké nálezy, tak jsou vypsané jen ty, které byly pro Coufala zajímavé, většinou je však jen stroze uvedeno, že se našla nějaká keramika nebo hřebíky, o přesném místě nálezu ale nepíše nikde. Dále se v deníku hlavně zmiňuje o množství odklizené hlíny, o počasí, náladě na pracovišti, o chování turistů v areálu hradu nebo popisuje, jakým způsobem na hrad každý pracovník přijel. Zápis je také občas doplněn drobnou kresbou nebo plánkem, kterým dovysvětluje situaci, kterou zrovna popisuje (Vaněčková 2017, 37).

Fotografická dokumentace k exkavaci je zastoupena jen několika žánrovými fotografiemi bez bližších popisků, některé jen zběžně dokumentují archeologický odkryv, postup prací, archeologickou situaci nebo nalezené předměty. Fotografiemi jsou dokumentovány i prováděné rekonstrukce hradního zdiva po roce 1960. Jako další forma dokumentace sloužilo Coufalovi schéma na papíře formátu $\mathrm{A} 3$, na který si upevňoval fotografie a k nim připsal popisek a schematický nákres se situací v hradu. Bohužel se nám tyto tabulky zachovaly bez přilepených fotografií, a na spoustě z nich již nelze poznat, kam která fotografie původně patřila (Mazáčková 2012, 84-85).

Kresebná dokumentace výzkumu je zastoupena jen základními plánky hradu, ve kterých jsou vyznačeny některé plochy odkryvu anebo dostavby některých zdí. Plánky jsou v měřítku 1 : 100 a jedná se o čtyři čelní pohledy na opravované zdi. Zakreslené jsou v původním stavu a pak s přestavbou (Mazáčková 2012, 84-84). V pozůstalosti B. Coufala se zachovaly i dva plánky celého areálu hradu (měřítko $1: 400$ ), tř̌i řezy kanálu u dolní věže (měřítko $1: 50$ ), nákres situace nalezeného zuhelnatělého zbytku dřevěné konstrukce z dolního paláce (měřítko $1: 20$ ), dvě kresebné rekonstrukce suterénu horního paláce a jedna kresba horního paláce. Kresebně 
byly zdokumentovány i některé vykopané předměty (např. šipky z kuše, kličč, keramika; Vaněčková 2017, 38).

\subsection{Rekonstrukce hradebního zdiva}

V šedesátých letech 20. století, po druhých exkavacích na Přímělkově, se B. Coufal vrátil na Rokštejn, tentokrát však k rekonstrukci hradního zdiva. Na hradě provedl velké množství zásahů do původního hradního zdiva a nechal provést velké množství dozdívek i rekonstrukcí, a to na stávajícím nebo na odkrytém zdivu hradu. K stavebním úpravám se dochovala jen částečná dokumentace v podobě žánrových fotografií a několika Coufalem nakreslených plánků, ve kterých však zaznamenal jen některé dostavby (Mazáčková 2012, 87).

Za pomoci místních zedníků rekonstruoval prostor východní věže a s ním i fragment zdiva souvisejícího s kovárnou. Dále rekonstruoval jihovýchodní nároží obvodové hradby horního hradu, kde propojil stávající fragment jižní hradby se západním pásem a částečně uzavřel prostor horního hradu. Následně nechal dozdít nároží horní věže, a nesouměrně vyzdil jihozápadní nároží vstupní brány do horního hradu. Rekonstrukci vstupní brány na nádvoří dolního hradu však provedl naprosto odlišně, než je doloženo na plánku z 18. století (Mazáčková 2012, 87).

\section{Revize Coufalovy dokumentace výzkumu}

Důkladným zrevidováním terénních deníků a veškeré dostupné dokumentace z pozůstalosti B. Coufala, zapůjčené ke zpracování jeho rodinou, se podařilo zjistit několik skutečností. Jak je zmíněno výše, B. Coufal si na velkoformátových papírech sestavoval fotografie ze svého archeologického výzkumu. Bohužel většina fotografického materiálu chybí, dochovaly se jen

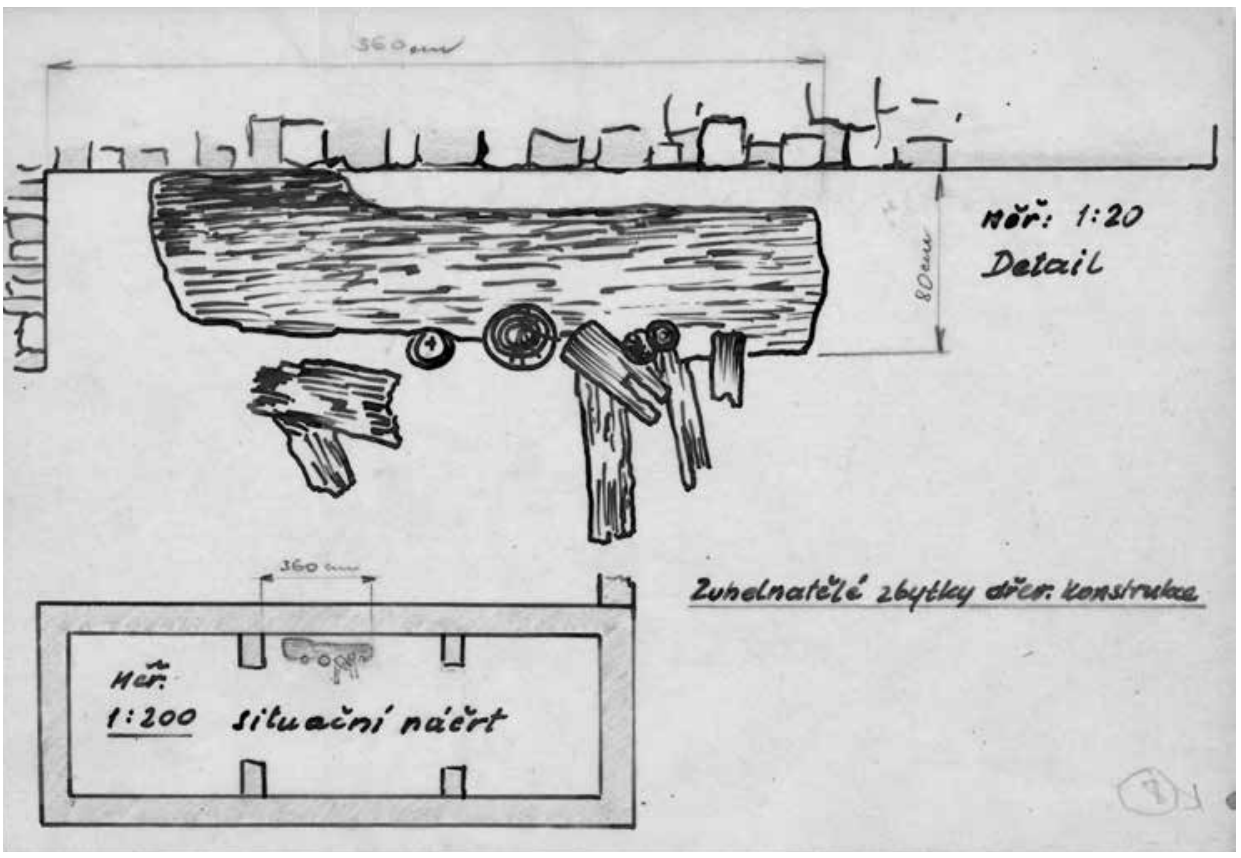

Obr. 4. Nález dřevěné zuhelnatělé konstrukce z dolního paláce, kresebná dokumentace. Autor B. Coufal, pozůstalost B. Coufala, archiv ÚAM.

Abb. 4. Fund einer verkohlten Holzkonstruktion aus dem unteren Palas, Zeichendokumentation. Erstellt von B. Coufal, Nachlass B. Coufal, Archiv Institut für Archäologie und Museologie. 


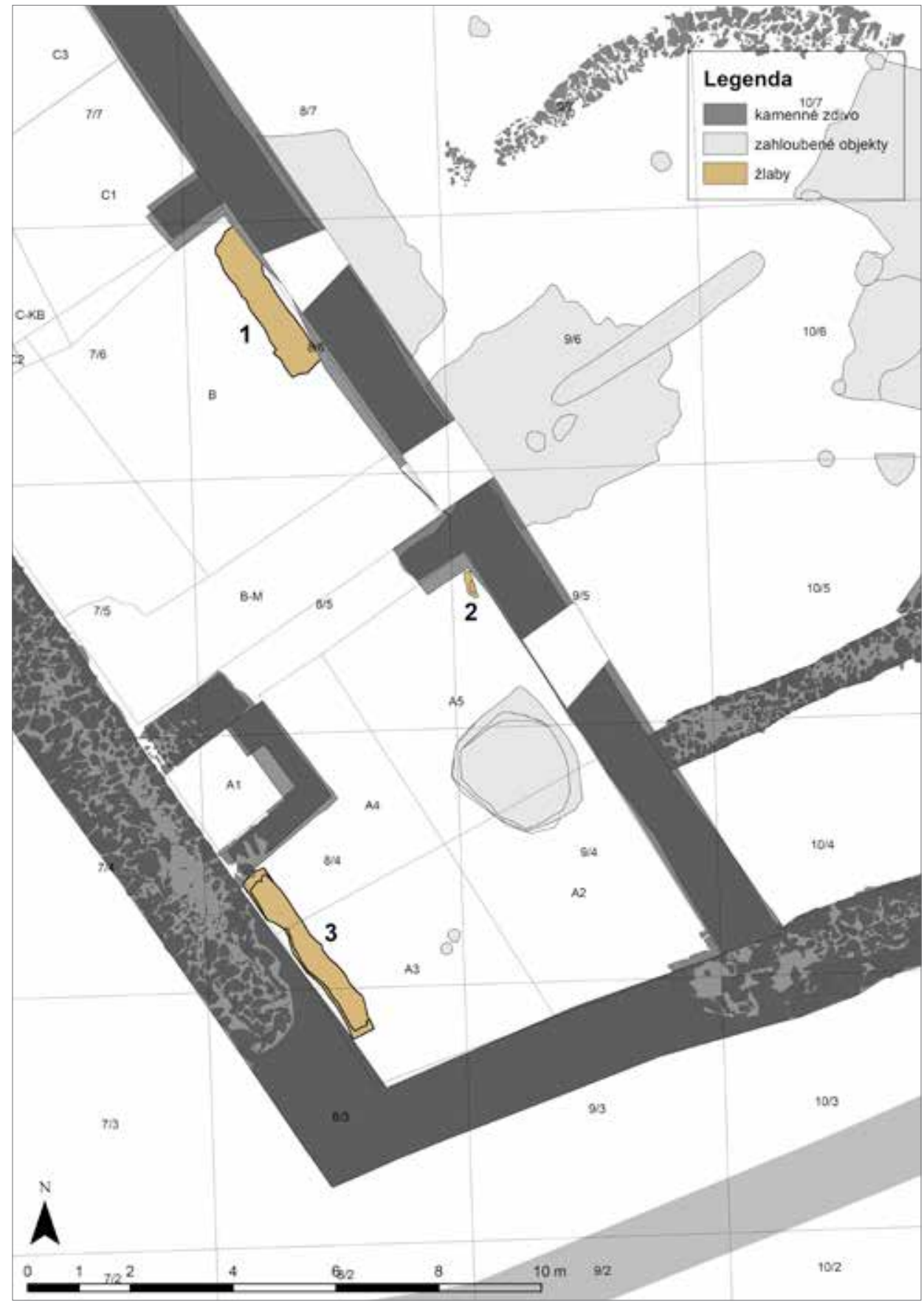

Obr. 5. Situace nálezů dřevěných žlabů v dolním paláci z výzkumu B. Coufala v prostoře $B$ a z výzkumu $Z$. Měřínského v prostoře A (2-3). Autor B. Coufal, pozůstalost B. Coufala, archiv ÚAM, upraveno.

Abb. 5. Fundsituation der Holzrinnen im unteren Palas von B. Coufals Grabung in Raum B und von Z. Měřínskýs Grabung in Raum A (2-3). Erstellt von B. Coufal, Nachlass B. Coufal, Archiv Institut für Archäologie und Museologie, bearbeitet. 

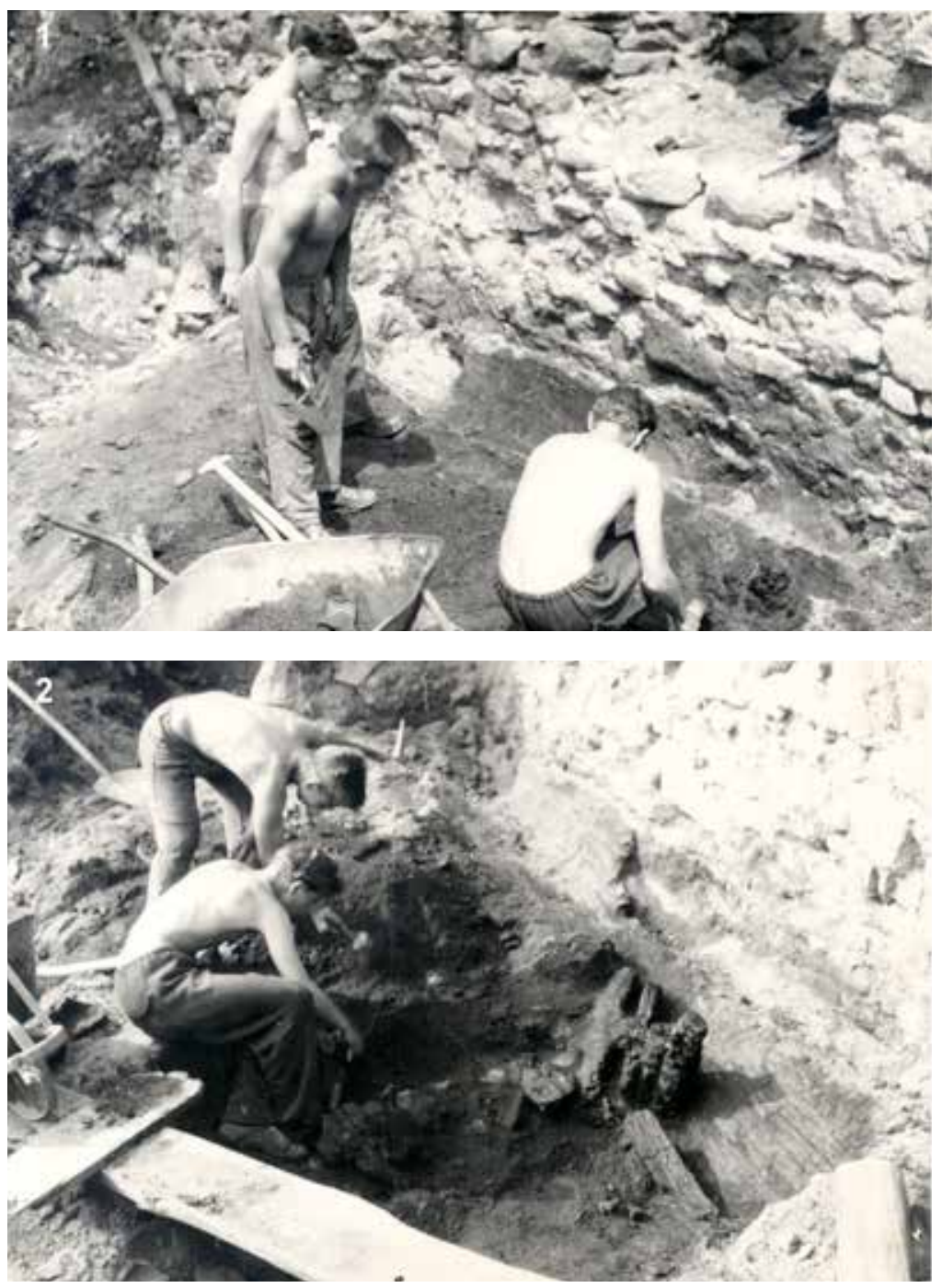

Obr. 6. Fotografická dokumentace B. Coufala z roku 1959. 1-2 - nález dř̌evěné zuhelnatělé konstrukce v dolním paláci v prostoře B. Autor B. Coufal, pozůstalost B. Coufala, archiv ÚAM.

Abb. 6. Fotodokumentation von B. Coufal aus dem Jahr 1959. 1-2 - Fund einer verkohlten Holzkonstruktion in Raum B des unteren Palas. Foto B. Coufal, Nachlass B. Coufal, Archiv Institut für Archäologie und Museologie.

připojené popisky a půdorysy se šipkami, které vysvětlují zachycenou situaci, a lze ji porovnat s popisy v terénních denících. Používání názvů budov palácium (horní palác), bašta (věž horního hradu), jižní budova nebo také zadní trakt či jižní trakt s předpokládaným padacím mostem (dolní palác) se objevilo poprvé na plánu z roku 1958, který byl postupně doplňován o další zkoumané úseky či dostavby (obr. 2; Coufal 1958, 1-9).

Fotografické tabule obsahují i nakreslené půdorysy obou paláců. Po jejich důkladném průzkumu se zjistilo odlišování obou paláců, které Coufal nakreslil přesně podle aktuálního stavu dochovaných zdí, a správně k nim umístil i orientaci na světové strany. Díky tomuto zjištění by 
se daly v budoucnu rozklíčovat další Coufalovy tabule s prázdnými místy po fotografiích, na které by se daly dochované snímky znovu poskládat. To by mohlo pomoci k odhalení průběhu vykopávek nebo k dešifrování některých archeologických situací. Např́iklad se tak povedlo zjistit, že dřevěná konstrukce, která byla během Coufalova výzkumu nalezena (obr. 4), nebyla objevena $\mathrm{v}$ horním paláci, jak se dř́ve předpokládalo, ale byla odkryta $\mathrm{v}$ dolním paláci. Toto zjištění podporuje i zápis v Coufalově deníku, ve kterém stojí, že nález dřevěné konstrukce se uskutečnil 8. července 1959 (obr. 5-6). V terénním deníku však neuvádí přesné místo nálezu, ale předchází zápis o odkryvech v zadním traktu (tedy dolní palác). Sondu v horním paláci otevírá kvůli stínu až následující den (Coufal 1959, 23). Proto je nadmíru jasné, že se dřevo původně našlo v prostoru $\mathrm{B}$ dolního paláce (obr. 5:1). Z dolního paláce prostory A pocházejí další zbytky dřevěných žlabů nebo koryt. Skoro čtyři metry dlouhé zuhelnatělé koryto se zbytky krmiva při jeho západní zdi a malý fragment v severovýchodním rohu prostory A (obr. 5:2, 3; Mazáčková $2012,115)$. Prostor A tak byl dlouho interpretován jako stáj pro koně nebo jako sklady, nově však Z. Havlická tento prostor interpretuje na základě archeobotanických zbytků jako možný pivovar či sladovnu (Havlická 2018, 91). Dokumentovaná archeologická situace spíše odpovídá primárním interpretacím jako stáje a sklady (Měřínský 2007). Samotná interpretace nálezové situace doloženým fragmentem dřevěného koryta či žlabu již byla mimo rámec zpracování archeobotanického materiálu. Není pravděpodobné, že by se v jedné místnosti vařilo pivo nebo vyráběl slad a zároveň v ní byli ustájeni koně.

\section{Vyhodnocení souboru kovových artefaktů z horního paláce}

Vyhodnocený železný inventář byl získán z pozůstalosti Ing. Bohumila Coufala. Všechny předměty by měly pocházet z výzkumu horního paláce hradu Rokštejna. Celkový počet kovových předmětů činí 277 kusů. Je pravděpodobné, že se nejedná o všechny železné předměty, které byly v paláci nalezeny. Podle dochovaných fotografií je zřejmé, že se některé předměty pohřešují. Otázkou zůstává, zda a kolik z těchto pohřešovaných artefaktů se dostalo do muzeí na Vysočině či v Brně (MZM Brno, MV Třebíč, MV Jihlava), nebo jestli jsou již nenávratně ztraceny (Vaněčková 2017, 45). Ke zpracování a typologickému určení souboru železných předmětů byla primárně využita práce R. Krajíce (2003, 60-209). Početní zastoupení jednotlivých kategorií kovových předmětů v souboru je vyneseno v tabulce (tab. 1).

\subsection{Stavební kování}

Do této skupiny náleží celkově 262 analyzovaných předmětů. Nejvíce jsou zastoupeny hřebíky (celkově 214 ks), dále petlice typu II a V (2ks), skoby typu II/1, III1 a IV/1 (5 ks), železné kování (35ks) a součásti zámku typ I a IV (6 ks).

Nejvíce hřebíků bylo určeno jako typ IIIa, což není samozřejmě nic překvapivého, jelikož tento typ hřebíku byl ve středověku nejpoužívanější (obr. 7:7-11). Další početnou skupinu tvořily hřebíky typu IV - hřebíky vypadají jako „křídláky“, ale mají na jedné straně vykováno jen jedno „křídlo“. Tyto hřebíky mohly mít svoji specifickou funkci, mohly být například využity jako věšáčky. Kvůli své specifické hlavičce mohl být tento typ hřebíků také použit ke zhotovení konstrukcí nábytku nebo mohly být využity jako spojovací prostředek dřevěné prkenné podlahy (Vaněčková 2017, 46-47). Nalezeny byly i ,šindeláky“ (obr. 7:1-4), které by mohly dokazovat, že palác měl někde malou stř́šku z došků nebo šindelů. Zastřešen mohl být např́íklad hlavní vstup do paláce. Při stavebním průzkumu L. Šabatové, M. B. Soukupa a T. Kyncla bylo zjištěno, že v původní úpravě portálu by mohly být pozůstatky související s konstrukcí zastřešení (Šabatová-Soukup-Kyncl 2010, 195). A podle dochovaných Coufalových tabulek s fotografiemi můžeme odhalit, že některé šindeláky byly nalezeny v prostoru mezi horní věží a horním palácem, proto je velmi pravděpodobné, že byl nějakým způsobem hlavní vstup do paláce zastřešen. Eventuálně však mohla být zastřešena i střecha arkýře s prevétem, který se nachází na západní straně paláce (Vaněčková 2017, 48, 65). 


\begin{tabular}{|c|c|c|c|}
\hline \multicolumn{4}{|l|}{ Stavební kování } \\
\hline \multirow{15}{*}{ Hřebíky } & Ia & $3 \mathrm{ks}$ & Inv. č. $454,455,456$ \\
\hline & $\mathrm{Ib}$ & $2 \mathrm{ks}$ & Inv. č. 353,361 \\
\hline & Ic & $1 \mathrm{ks}$ & Inv. č. 399 \\
\hline & IIa & $1 \mathrm{ks}$ & Inv. č. 362 \\
\hline & IIIa & $\begin{array}{c}102 \\
\mathrm{ks}\end{array}$ & $\begin{array}{l}\text { Inv. č. } 355,381,387,389,391-393,397,400,429,431,436,437, \\
440-443,445,447-449,452,460,479,481-484,487,490-494, \\
497-499,502,506, \text { ID } 7-9,11,13,14,15,19-26,32,33,39,42-52, \\
54-57,63-69,71-73,76-78,82,84-99\end{array}$ \\
\hline & $\mathrm{IIIb}$ & $19 \mathrm{ks}$ & $\begin{array}{l}\text { Inv. č. } 376,380,388,401,433,480,485,486,488,503 \text {, ID 17, 18, } 34 \text {, } \\
40,41,53,70,74,75\end{array}$ \\
\hline & IV & $29 \mathrm{ks}$ & $\begin{array}{l}\text { Inv. č. } 394,403,444,446,453,458,459,461,474,489,500, \text { ID } 1-4 \text {, } \\
12,14,27-31,58,59,62,79-81,83\end{array}$ \\
\hline & $\mathrm{Va}$ & $2 \mathrm{ks}$ & Inv. č. 495,496 \\
\hline & $\mathrm{Vb}$ & $2 \mathrm{ks}$ & Inv. č. 377,434 \\
\hline & $\mathrm{Vc}$ & $21 \mathrm{ks}$ & Inv. č. $344-351,372-374,415-423,462$ \\
\hline & VIIIa & $27 \mathrm{ks}$ & $\begin{array}{l}\text { Inv. č. } 354,359,360,371,378,390,396,398,404,428,430,432, \\
438,439,450,457,501,504,505 \text {, ID 5, 6, 35-38, 60, 61 }\end{array}$ \\
\hline & VIIIb & $1 \mathrm{ks}$ & Inv. č. 379 \\
\hline & VIIIc & $1 \mathrm{ks}$ & Inv. č. 395 \\
\hline & IX & $2 \mathrm{ks}$ & Inv. č. 375,435 \\
\hline & Neurčitelný & $1 \mathrm{ks}$ & Inv. č. 402 \\
\hline \multirow[t]{2}{*}{ Petlice } & Typ II, osmičková & $1 \mathrm{ks}$ & Inv. č. 384 \\
\hline & $\begin{array}{l}\text { Typ V, pevná } \\
\text { petlice }\end{array}$ & $1 \mathrm{ks}$ & Inv. č. 426 \\
\hline \multirow{3}{*}{$\begin{array}{l}\text { Dvouramenné } \\
\text { skoby }\end{array}$} & Typ II/1 & $1 \mathrm{ks}$ & Inv č. 363 \\
\hline & Typ III/1 & $3 \mathrm{ks}$ & Inv. č. $356,357,365$ \\
\hline & Typ IV/1 & $1 \mathrm{ks}$ & Inv. č. 364 \\
\hline \multirow{5}{*}{ Plechové kování } & Neurčité kování & $9 \mathrm{ks}$ & Inv. č. $467-473477,478$ \\
\hline & Drobné zlomky & $11 \mathrm{ks}$ & ID 10 \\
\hline & Kování truhlice & $13 \mathrm{ks}$ & Inv. č. $405-409,411,413,414,464-466,475,476$ \\
\hline & $\begin{array}{l}\text { Dvouramenný } \\
\text { pant }\end{array}$ & $2 \mathrm{ks}$ & Inv. č. 410,412 \\
\hline & Držadla & $2 \mathrm{ks}$ & Inv. č. 450,451 \\
\hline \multirow{2}{*}{ Zámek } & Typ I & $4 \mathrm{ks}$ & Inv. č. 366-369 \\
\hline & Typ IV & $2 \mathrm{ks}$ & Inv. č. 382,383 \\
\hline \multicolumn{4}{|c|}{ Zemědělské nářadí } \\
\hline Srp & Typ II & $1 \mathrm{ks}$ & Inv. č. 424 \\
\hline Kování cepu & Závěs cepu & $2 \mathrm{ks}$ & Inv. č. 370 \\
\hline \multicolumn{4}{|l|}{ Řemeslné nástroje } \\
\hline Nebozez & & $1 \mathrm{ks}$ & Inv. č. 358 \\
\hline Sekáč & Lod'kovitý & $1 \mathrm{ks}$ & Inv. č. 352 \\
\hline Pila & & $1 \mathrm{ks}$ & Inv. č. 427 \\
\hline \multicolumn{4}{|l|}{ Součást vozu } \\
\hline Kování oje & & $1 \mathrm{ks}$ & Inv. č. 386 \\
\hline
\end{tabular}




\begin{tabular}{|l|l|l|l|}
\hline \multicolumn{3}{|l|}{ Mobiliáŕ usedlostí a provozní vybavení } \\
\hline Kovová nádoba & $1 \mathrm{ks}$ & Inv. č. 885 \\
\hline Neurčitelné & 2 ks & Inv. č. 385, 425 \\
\hline $\begin{array}{l}\text { Železné } \\
\text { predměty }\end{array}$ & & \\
\hline
\end{tabular}

Tab. 1. Analyzovaný železný inventář z horního paláce hradu Rokštejna z amatérského archeologického výzkumu B. Coufala $v$ letech 1958-1959.

Tab. 1. Analysiertes Eiseninventar aus dem oberen Palas von Burg Rokštejn von der von B. Coufal in den Jahren 1958-1959 durchgeführten archäologischen Amateurgrabung.
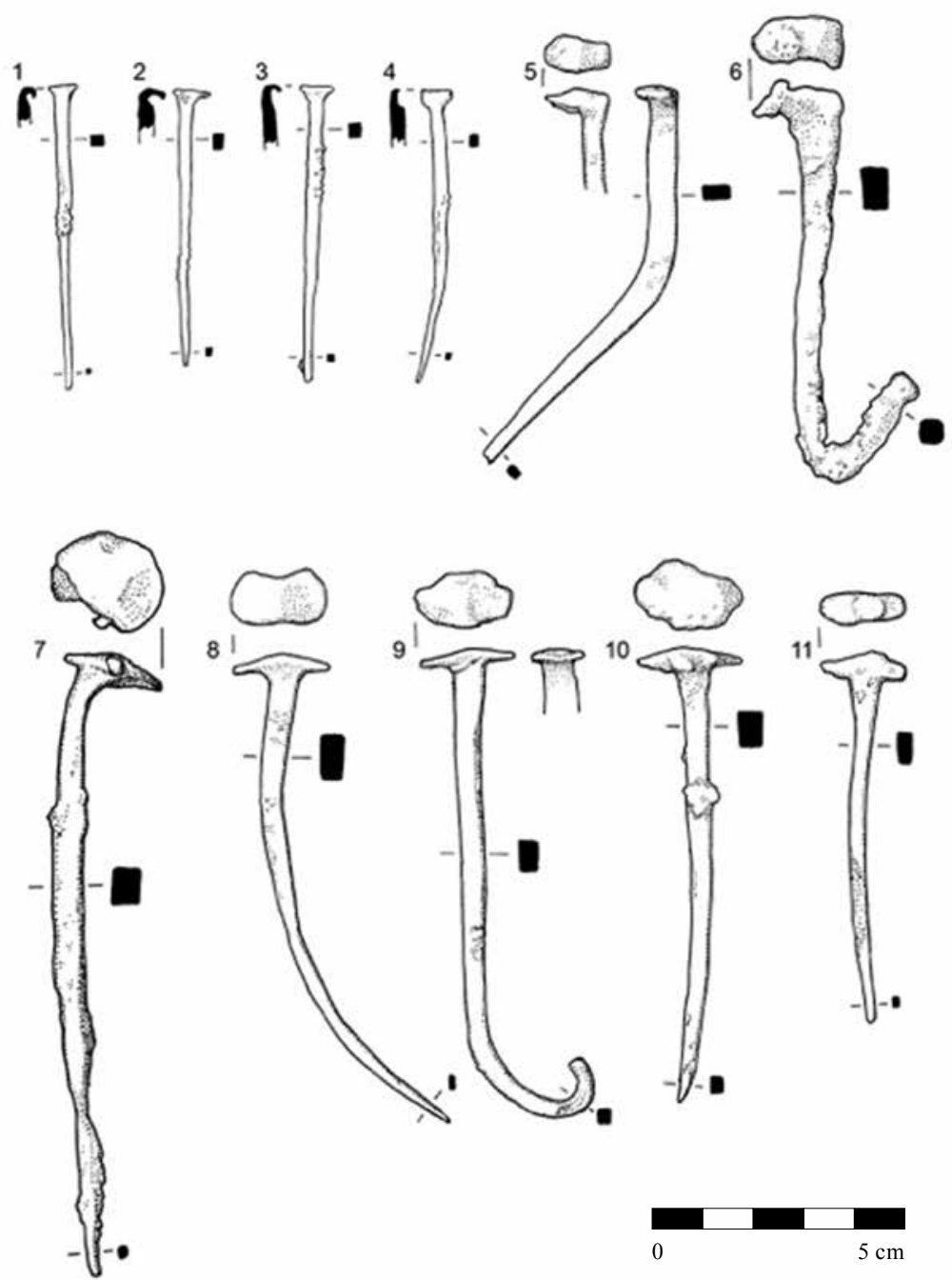

Obr. 7. Hřebíky z výzkumu horního paláce hradu. Kresba S. Plchová.

Abb. 7. Nägel von der Grabung am oberen Palas der Burg. Zeichnung S. Plchová. 
Větší počet předmětů v analyzovaném souboru zastupovaly i různě velké fragmenty železného kování. Většina z nich byla interpretována jako možné kování truhlice či jiného nábytku (Vaněčková 2017, 50). V souboru se nacházejí hlavně závěsy - panty se stylizovaným ukončením a s otvory pro hřebíky. Kromě nich ještě soubor obsahuje drobné plíšky, ale i větší plechy, které byly součástí výzdoby na truhličce. Jeden fragment je zahnutý a kopíruje tak tvar dřevěné konstrukce, mohl být např́klad umístěn na rohu bedničky. Analogické nálezy ke kování nábytku popisuje R. Krajíc pro Sezimovo Ústí (Krajíc 2003, 80) a Z. Měchurová pro Konůvky (Měchurová 1997, 110-111). Dále se v souboru nacházely dva dvouramenné panty s kloubem a dvě držadla. Je možné, že nález tohoto kování truhlice si Coufal zapsal i do svého deníku, ve kterém ho špatně interpretuje a píše o něm jako o kování z dvířek. Jelikož se v souboru ani na fotkách nevyskytuje jiné kování, které by mohlo být s jeho interpretací spojeno, lze se domnívat, že se jedná právě o nález tohoto kování - interpretovaného jako kování z truhlice. Truhlice se mohla nacházet $\mathrm{v}$ některém podlaží v západní části v prostoře $\mathrm{A}$ horního paláce. Pokud byla umístěna ve třetí nebo čtvrté úrovni, mohla patřit ke hmotnému vybavení soukromých komnat a mohl být do ní ukládán oděv nebo jiné osobní předměty. Samozřejmě mohla truhlice sloužit např́íklad jako pokladnice na uložení peněz, zlata nebo jiných cenností, či významných listin a dokumentů, o které se zmiňuje ve svých dopisech Zdeněk z Valdštejna (Mazáčková 2012, 182). Místnost v druhém podlaží prostory A mohla sloužit jako jakási kancelář, nebo dokonce jako pokladnice, a podle stavebního průzkumu L. Šabatové, M. B. Soukupa a T. Kyncla bylo možné dveře do této místnosti zajistit závorou (Vaněčková 2010, 64; Šabatová-Soukup-Kyncl 2010, 195).

Zajímavým objektem je plechové kování, které má na sobě spoustu (ca 40) malých otvorů a na jednom konci má dochovaný menší hřebíček. Jeho původní funkce je neznámá. Mohlo by se jednat o nějaký druh výzdoby na kování nábytku, nebo otvory v plíšku mohly sloužit jako průduchy, či mohly mít podobnou funkci jako cedník, síto nebo sypátko (Vaněčková 2017, 51). Analogie k tomuto předmětu sice existují, ale nejsou úplně shodné. Např́íklad nálezy z Konůvek (Měchurová 1995, 175, 184) a Krásné nad Hornádom (Polla 1986, 265, 266, 277) se odlišují tím, že otvory jsou proražené symetricky a tvoří řady. Fragment ze Sarvaly (Holl-Parádi 1982, obr. 141:13) má zase otvory větší než ty, co jsou na plíšku z Rokštejna.

\subsection{Zemědělské nářadí a řemeslné nástroje}

Do skupiny zemědělského nářadí byly přiřazeny dva nálezy, a to srp (typ II) a fragment kování závěsu cepu. Jako řemeslné nástroje byly v souboru určeny celkem tř̌i předměty. Jednalo se o dř́k z nebozezu, fragment listu pily a předmět, který byl určen jako sekáč. Tento sekáč je však opět mírně záhadným předmětem, ačkoliv se podobá noži, nenese žádné stopy po nýtech nebo trnu k upevnění rukojeti. Překvapivé je i to, že jediné analogie k tomuto předmětu pocházejí z Př́mělkova, a rovněž byly nalezeny B. Coufalem. Otázkou tedy je, zda se nejedná o místní specifické nástroje, nebo zda to nemohou být recentní předměty z Coufalova výzkumu (Vaněčková 2017, 55-56).

\subsection{Součásti vozu a mobiliář usedlostí}

Jako součást vozu by mohl být interpretován jeden předmět, jedná se o kování oje vozu. Do skupiny „mobiliář usedlostí“ byly určeny artefakty, které byly interpretovány jako fragmenty kovové nádoby. Fragmenty byly změřeny na XRF spektrometru Delta Professional model 54228, který prokázal mosaz jako surovinu, z níž byla nádoba vyrobena (Vaněčková 2017, 57).

\section{Závěr}

Zpracování pozůstalosti po Ing. B. Coufalovi o výzkumu hradu Rokštejna přineslo některá nová fakta o odkrytých situacích a jejich možné interpretaci na základě vyhodnocení archeologického materiálu. 
Vektorizace Coufalových plánů a odkryv subrecentních a recentních opětovně zasypaných sond přinesl jejich nové geodetické zaměření a zjištění o narušení původních situací. Některé nově odkryté staré sondy byly spojeny právě s Coufalovým výzkumem hradu v letech 19581960 a dovolily lepší interpretaci zjištěných situací, např́íklad v areálu horního hradu ve čtverci 3/10. Nenávratně jsou ztracené situace $\mathrm{z}$ obou paláců a výzkumu šachty s odpadním kanálem. Lze je pouze jen hypoteticky a na základě dochované dokumentace a obecných popisů rekonstruovat i s odkazem na systematicky zkoumané plochy dolního paláce i revize v horním paláci.

Mezi důležitá zjištění a propojení s provozem dolního paláce je umístění dřevěného prvku $\mathrm{v}$ prostoře $\mathrm{B}$ a jeho analogie $\mathrm{v}$ prostoře $\mathrm{A}$ a doložení využití suterénu dolního paláce $\mathrm{v}$ závěrečném horizontu hradu jako ustájení pro koně. Obrovské množství archeobotanického materiálu může souviset s krmivem pro koně, velké množství ječmenu, stejně jako využití vyšších podlaží paláce jako skladovacích prostor. Situace v prostoře $C$ dolního paláce byla ještě otevřená v roce 1788, krátce nato uzavřel zánikový horizont této prostory př́krov kamenné destrukce přičky mezi prostorami B a C (Mazáčková 2012, 78). Depoziční a postdepoziční procesy, které proběhly od pádu hradu do pádu zděné prř́čky, změnily shořelé dřevěné konstrukce v jednolitou černou požárovou vrstvu s nižším obsahem archeobotanického materiálu bez dokladů zuhelnatělých dřevěných konstrukcí. Situace z prostory A a patrně z prostory B se zde neopakovala.

Ve zpracovávaném souboru kovových předmětů se nenacházejí žádné chronologicky citlivé předměty. Jedná se především o pozůstatky stavebních kování jako hřebíků a skob. V souboru jsou zastoupeny srp a kování cepu a mobiliář paláce jako kování truhlice. I když nemáme přesnější informace o jejich poloze či hloubce, ve které se nacházely, lze celý soubor z horního paláce na základě porovnání kontextu archeologické situace v prostoře $\mathrm{B}$ horního paláce a při porovnání situace $\mathrm{s}$ dolním palácem položit do období fungování paláce a závěrečné existence hradu včetně jeho zánikového horizontu, tedy nejpozději k roku 1467 (Mazáčková 2017, 762).

\section{Prameny}

COUFAL, B., 1958-1960: Terénní deníky z archeologického výzkumu hrádku Př́mělkov-Spády a hrad Rokštejn, rukopis, digitalizace, ulož. v ÚAM FF MU, Brno.

\section{Literatura}

HAVLICKÁ, Z., 2018: Analýza rostlinných makrozbytků požárových vrstev dolního paláce na hradě Rokštejn. Magisterská diplomová práce, ulož. v ÚAM FF MU, Brno.

HOLL, I.-PARÁDI, N., 1982: Das mittelalterliche Dorf Sarvaly. Fontes Archaeologici Hungariae. Budapest. MAZÁČKOVÁ, J., 2012: Militária z hradu Rokštejna v širším stř̌edoevropském kontextu. Disertační práce, ulož. v ÚAM FF MU, Brno.

MĚCHUROVÁ, Z., 1995: Železné předměty ze zaniklé stř̌edověké vsi Konůvky na Slavkovsku (okr. Vyškov), ČMZM LXXX, 141-197.

- 1997: Konůvky - zaniklá středověká ves ve Ždánickém lese. Studie AÚ AV ČR v Brně XVII/1. Brno.

MĚŘÍNSKÝ, Z., 1990: Zemřel Ing. Bohumil Coufal, VVM XLII, 428.

KRAJÍC, R., 2003: Sezimovo Ústí. Archeologie středověkého poddanského města 3. Kovárna v Sezimově Ústí a analýza výrobků ze železa. Díl I. Praha - Sezimovo Ústí - Tábor.

POLLA, B., 1986: Košice - Krásná. K stredovekým dějinám Krásnej nad Hornádom. Fontes AÚ SNM V Bratislave. Tomus VIII. Bratislava.

ŠABATOVÁ, L.-SOUKUP, M. B.-KYNCL, T., 2010: Nové poznatky z průzkumu hradu Rokštejn - Neue Erkenntnisse aus den Untersuchungen der Burg Rokštejn. In: Dějiny staveb. Sborník příspěvků z konference Dějiny staveb 2009, 193-209. Plzeň.

VOHRYZEK, S., 2009: Hrádek Př́mělkov (okr. Jihlava). Magisterská diplomová práce, ulož. v ÚAM FF MU, Brno.

VANĚČKOVÁ, D., 2017: Archeologické výzkumy ing. B. Coufala v areálu hradu Rokštejna. Bakalářská diplomová práce, ulož. v ÚAM FF MU, Brno. 


\section{Zusammenfassung}

\section{Die archäologischen Grabungen von Ing. B. Coufal im Areal von Burg Rokštejn}

Die Bearbeitung des Nachlasses von Ing. Bohumil Coufal über die Grabung auf Burg Rokštejn lieferte einige neue Fakten zu den freigelegten Situationen und ihrer möglichen Interpretation anhand der Auswertung des archäologischen Materials. Ing. Bohumil Coufal (Abb. 1) wurde am 18. August 1907 in Kosov bei Jihlava geboren. Sein Vater Emil Coufal erwarb im Jahr 1906 Immobilien, die sich in der Nähe von Burg Rokštejn befanden. Bei ihnen handelte es sich um eine ehemalige Papierfabrik und deren Betriebsgebäude, die sich genau auf dem nördöstlichen Zwinger und in der nördlichen Vorburg der Burg befanden. Das Gebäude der Papierfabrik wurde im Jahr 1908 zu einer modernen Getreidemühle umgewandelt, die ab 1920 mit einer Francis-Turbine ausgestattet war und damit begann, die umliegenden Dörfer mit elektrischem Strom zu versorgen. Die Mühle funktionierte bis zum Jahr 1958, im Jahr 1990 ist sie abgebrannt. Das Gebäude in der nördlichen Vorburg wurde zu einem Einfamilienhaus umgebaut, in dem B. Coufal seine ganze Kindheit und die meiste Zeit seines Lebens verbrachte. Seine Familie lebt bis heute dort (Mazáčková 2012, 10, 67, 518; Vaněčková 2017, 19).

B. Coufal widmete sich intensiv der heimatkundlichen und archäologischen Forschung in der Mikroregion Černé lesy (Schwarze Wälder), hauptsächlich um die Dörfer Přímělkov und Panská Lhota in der Region Jihlava. In den Jahren 1957 und 1960 führte er seine ersten amateurhaften Aushebungen an einer befestigten Burg in der Lage Přímělkov - Spády durch, die sich auf einem Bergsporn oberhalb des Zusammenflusses der Flüsse Jihlava und Brtnice ca. 1,5 km östlich von Burg Rokštejn befindet (Měřínský 1990, 428; Vohryzek 2009, 10).

Auf Burg Rokštejn führte B. Coufal in den Jahren 1958-1965 eine Amateurgrabung durch, und zwar mit dem Wissen des Mährischen Landesmuseums in Brno und des Kommunalkomitees von Jihlava. Auf der Burg untersuchte er beispielsweise den Kanal an der sog. Schmiede im Areal der unteren Burg, den Raum A des oberen Palas, Raum B des unteren Palas, die südwestliche Ecke des Hofes der oberen Burg und das Tor am Hof der unteren Burg (Abb. 2-3). Außer der archäologischen Grabung rekonstruierte und sicherte er auch einige Teile des gestörten Burgmauerwerks - die südwestliche Ecke der Wehrmauer der oberen Burg, die Wehrmauer im Abschnitt nördlich vom Turm der unteren Burg in den Quadraten 14/13 und 14/14 - und vervollständigte das Tor der unteren Burg (Vaněčková 2017, 20).

Eine Vektorisierung von Coufals Plänen und Freilegungen wiederholt zugeschütteter subrezenter und rezenter Sondierschnitte brachte ihre neue geodätische Vermessung und die Feststellung einer Störung der ursprünglichen Situationen mit sich. Einige neu freigelegte alte Sondierschnitte wurden gerade mit Coufals in den Jahren 1958-1960 durchgeführter Grabung in Verbindung gebracht und erlaubten eine bessere Interpretation der festgestellten Situationen, beispielsweise im Areal der oberen Burg in Quadrat 3/10. Irreversibel sind die verlorenen Situationen von beiden Palassen und der Grabung an einem Schacht mit Abwasserkanal. Ihre Situation lässt sich nur hypothetisch und anhand der erhalten gebliebenen Dokumentation und allgemeinen Beschreibungen sowie mit einem Verweis auf die systematisch untersuchten Flächen des unteren Palas und der Revision im unteren Palas rekonstruieren.

$\mathrm{Zu}$ den wichtigen Feststellungen und hergestellten Zusammenhänge mit dem Betrieb des unteren Palas zählt die Lage eines Holzelementes in Raum B und seine Analogie in Raum A sowie der Nachweis der Nutzung des Souterrains des unteren Palas im abschließenden Horizont der Burg als Stallung für Pferde (Abb. 5-6). Eine riesige Fülle archäobotanisches Material - eine große Menge Gerste, wie auch die Nutzung der höheren Stockwerke des Palas als Lagerraum kann mit Pferdefutter zusammenhängen. Die Situation in Raum C des unteren Palas war noch im Jahr 1788 offen, kurz darauf wurde der Untergangshorizont dieser Räume durch die Steinschicht der zerstörten Trennwand zwischen den Räumen B und C abgeschlossen (Mazáčková 2012, 78). Die depositären und postdepositären Prozesse, die seit dem Einsturz der Burg bis zum Einsturz der Trennmauer erfolgten, veränderten die verbrannten Holzkonstruktionen zu einer homogenen 
schwarzen Brandschicht mit geringerem Anteil an archäobotanischem Material ohne Belege der verkohlten Holzkonstruktionen. Die Situation aus den Räumen A und offenbar auch aus Raum B hat sich hier nicht wiederholt.

In der bearbeiteten Kollektion der Metallgegenstände befinden sich keine chronologisch sensiblen Gegenstände. Bei ihnen handelt es sich vor allem um Überreste von Baubeschlägen wie Nägel und Bauklammern. In der Kollektion sind eine Sichel und ein Dreschflegelbeschlag vertreten, und das Mobiliar des Palas in Form eines Truhenbeschlags. Obgleich wir über keine genaueren Informationen über ihre Lage oder Tiefe verfügen, in der sie sich befanden, kann die ganze Kollektion des oberen Palas anhand eines Vergleiches des Kontextes der archäologischen Situation in Raum B des oberen Palas mit der Situation des unteren Palas in die Funktionszeit des Palas und in die Abschlusszeit der Existenz der Burg einschließlich ihres Untergangshorizontes gelegt werden, also spätestens in das Jahr 1467 (Mazáčková 2017, 762).

Der vorliegende Beitrag basiert auf einer Bachelorarbeit, die sich mit den von Ing. B. Coufal im Areal von Burg Rokštejn durchgeführten archäologischen Grabungen beschäftigte (Vaněčková 2017).

Mgr. Jana Mazáčková, Ph.D., Ústav archeologie a muzeologie Filozofické fakulty Masarykovy univerzity, Joštova 13, 66243 Brno, Česká republika, jkrejsov@phil.muni.cz

Bc. Daniela Vaněčková, Ústav archeologie a muzeologie Filozofické fakulty Masarykovy univerzity, Joštova 13, 66243 Brno, Česká republika, 438568@mail.muni.cz 
